\title{
Misel o glasbi v spisih treh slovenskih medvojnih glasbenih esejistov
}

\author{
Jurij Snoj \\ Znanstvenoraziskovalni center SAZU \\ Research Centre of the Slovenian Academy of Sciences and Arts
}

$\mathrm{V}$ času med obema vojnama je bilo slovensko pisanje o glasbi raznovrstno in raznoliko: Dnevno časopisje in kulturne revije so v obliki kritik redno spremljale glasbeno življenje; objavljali so se kritični pregledi koncertnih in opernih sezon; nekateri pisci so pisali kolumne $\mathrm{z}$ aktualno glasbeno vsebino; potekale so polemike o glasbenoorganizacijskih vprašanjih. V vsem tem, sprotno glasbeno življenje spremljajočem pisanju je mogoče prepoznavati miselna in estetska izhodišča, kot so jih imeli posamezni pisci. Poleg tega so nastajale glasbenozgovinske študije, ki so se raziskovalno posvečale temam iz slovenske glasbene zgodovine, kot tudi razni pregledi posameznih segmentov evropske glasbene zgodovine. Nenazadnje so nekateri glasbeniki in intelektualci snovali daljša esejistična besedila, ki so se lotevala estetskih vprašanj o glasbi, ne da bi bila ta neposredno vezana na sprotno glasbeno dogajanje.

Ljudi, ki so tako ali drugače pisali o glasbi, ni bilo malo, in kar so zapustili, je mogoče obravnavati iz različnih zornih kotov. Če se omejimo na glasbene esejiste, je bilo že pred časom imlicitno nakazano, da so bili med njimi najpomembnejši trije: skladatelj Anton Lajovic, skladatelj Marij Kogoj in umetnostni zgodovinar Stanko Vurnik. ${ }^{1} \mathrm{Ne}$ le, da so zapustili razmeroma obsežen glasbenoesejistični opus; v svojih spisih so razvijali misel o glasbi, ki je zanimiva tako v svojem zgodovinskem kontekstu kot tudi sama po sebi.

1 Primož Kuret, Umetnik in družba. Slovenska glasbena misel po prvi vojni. Lajovic, Kogoj, Vurnik (Ljubljana: Državna založba Slovenije, 1988). 
Teme, ki so se jih lotevali Lajovic, Kogoj in Vurnik, so bile raznovrstne. Po eni strani so se odzivali na sprotno glasbeno življenje in reševali kulturnopolitična vprašanja - slednje zlasti Lajovic; hkrati so razvijali misel o glasbi sami; Vurnik se je poleg tega v povezavi z estetskimi vprašanji ukvarjal tudi z zgodovino glasbe. Njihovo pisanje je bilo že večkrat predmet muzikoloških obravnav in raznih komentarjev. Prvo daljšo študijo o njihovem publicističnem in esejističnem delu je prispeval izdajatelj njihovih spisov P. Kuret. ${ }^{2}$

Pisanje omenjenih treh esejistov je odprto za razna vprašanja; zlasti se postavlja vprašanje izvora njihovih misli ter vprašanje, kako so bile povezane s siceršnjimi miselnimi tokovi na Slovenskem in v srednji Evropi. To besedilo opazuje njihov esejistični opus iz specifičnega zornega kota: sprašuje se, kako so omenjeni trije pojmovali glasbo kot umetnost in kako so pojmovali njeno mesto in vlogo $\mathrm{v}$ družbi. $Z$ drugimi besedami želi prikazati, kako so bodisi neposredno ali implicitno odgovarjali na vprašanja: Kaj je glasba, kako nastaja, kaj je pri nastajanju nove glasbe odločilno, kaj je njen smisel.

Preden se lotimo obravnave, je potreben metodološki premislek. Upoštevati je treba, da spisi imenovanih treh piscev niso istovrstni: Kogoj je bil prvenstveno umetnik, ki ni bil razgledan po glasbenoestetski literaturi; svoje glavne misli je temu ustrezno zbral v eseju, spisanem na umetniško prosti način. Lajovic se je kot poklicni pravnik zanimal za sociološka vprašanja in njegovi esejistični spisi so nastajali predvsem $\mathrm{v}$ zvezi $\mathrm{z}$ aktualnimi kulturnimi dilemami časa. Lajovičevi in Kogojevi spisi že po svojem žanru niso taki, da bi sistematično obravnavali glasbenoestetska vprašanja (kot si jih zastavlja ta spis). Vurnik je bil umetnostni zgodovinar in se je z vprašanji umetnosti ukvarjal poklicno, vendar je bil tudi on pogosto esejistično prost. Za sodobnega bralca to pomeni, da mora misli imenovanih treh esejistov na neki način izpeljati iz njihovih spisov in jih na osnovi vzporedno primerjalnega branja mestoma tudi rekonstruirati; da bi bile prav razumljive in medsebojno primerljive, jih je treba obnoviti v sodobnem jezi$\mathrm{ku}$, večkrat tudi z drugimi izrazi, kot so jih uporabljali omenjeni trije sami.

I

Začnimo z najstarejšim od treh, s skladateljem Antonom Lajovicem (18781960), ki ga slovensko glasbeno zgodovinopisje prepoznava kot enega od

2 Primož Kuret, »Slovenska glasbena misel po prvi vojni«, v: Primož Kuret, Umetnik in družba, 7-79. 
predstavnikov slovenske glasbene moderne..$^{3}$ Lajovic, ki je doraščal in študiral za časa monarhije, je bil v medvojnem obdobju v svojih zrelih letih. Njegovi pogledi so bili že večkrat analizirani in komentirani. ${ }^{4}$

Lajovic je glasbeno kulturo primerjal $\mathrm{z}$ jezikom in jo razumeval podobno kot literaturo, v tem smislu: Kot ima vsak narod svoj jezik, v katerem se sporazumeva, tako ima tudi svojo umetnost in svojo glasbo. Jezik je Lajovic razumel kot pristni izraz naroda; tako naj bi bila tudi glasba nekega naroda njegov pristni izraz. 5 to glasbo ni mislil le ljudske glasbe; bolj kot to si je predstavljal, da mora biti pristni izraz narodne skupnosti tisto, kar nastaja na novo, se pravi glasba skladateljev, delujočih $\mathrm{v}$ dani narodni skupnosti. Zdelo se mu je, da je glasba, ki nastaja znotraj določene narodne skupnosti, res razumljiva le njej, podobno kot zares razumejo jezik le tisti, ki se v njem sporazumevajo.

Lajovic je bil velik občudovalec nekaterih skladateljev, zlasti čeških in ruskih; kljub temu pa je bil - skladno s predstavljenimi mislimi - zadržan in skeptičen do tega, da bi skladatelji enega naroda slepo posnemali glasbo skladateljev drugih narodov: da bi se npr. Čehi zgledovali pri Nemcih in komponirali tako kot nemški skladatelji, ali pa da bi to delali slovenski skladatelji. ${ }^{6} \mathrm{~V}$ tem smislu je odklanjal internacionalizem. Sumničil je, da je internacionalizem zgolj pretveza za prevlado ene nacionalne kulture nad drugo in pretveza za to, da se nacionalna kultura enega naroda omeji ali celo zatre. Odklanjal je mnenje, da je lepota glasbenih del, npr. Bachovih, Beethovnovih, Wagnerjevih, nekaj absolutnega in da obstoji sama zase neodvisno od kulture narodne skupnosti, znotraj katere so nastala. ${ }^{7}$ Nasprotno temu, da bi skladatelji danega naroda posnemali glasbo drugih glasbenih kultur, je bil prepričan, da morajo poiskati, najti, ustvariti nekaj, kar ne bi bilo posnemanje nečesa že obstoječega, pač pa bi kot nekaj novega izšlo iz lastnega naroda, iz življenja njihove lastne narodnostne skupnosti. Ta narodna skupnost bi v tem smislu nastalo novo glasbo po njegovem mnenju lahko tudi razumela in sprejela za svojo, jo recipirala.

3 Gregor Pompe, »Glasba slovenske povojne moderne«, De musica disserenda 12, št. 2 (2016): 27 .

4 Dragotin Cvetko, Glasbeni svet Antona Lajovca (Ljubljana: SAZU, 1985), 48-60, 6794. Kuret, »Slovenska glasbena misel po prvi vojni«, 14-38.

5 Anton Lajovic, »O večnih krasotah in o strupu Beethovnovih, Bachovih in Wagnerjevih del«, v: Kuret, Umetnik in družba, 124. Anton Lajovic, »Misli o umetnostni politiki«, v: Kuret, Umetnik in družba, 173.

6 Lajovic, »O večnih krasotah in o strupu Beethovnovih, Bachovih in Wagnerjevih del $\ll, 125$.

$7 \quad$ Prav tam, 127 
Glede vprašanja, kako naj bi se to dogajalo, kako naj bi skladatelj ustvarjal novo glasbo kot del lastnega naroda, je šel Lajovic še korak dlje. Iz lastne skladateljske izkušnje je vedel, da je nastanek umetniškega dela težko razložljiv in tudi misteriozen proces. Tisto, kar vodi umetnika pri njegovem delu, kar ga usmerja, je sam imenoval z izrazom »ideal«, pri čemer se je zavedal, da to ni najboljši izraz. Iz celotnega konteksta njegovih misli je mogoče razbrati, da si je $\mathrm{z}$ »idealom « predstavljal neko vodilo, ki ga ima ustvarjajoči skladatelj pred svojimi očmi, čemur skuša slediti in z ozirom na kar se iz trenutka $v$ trenutek odloča; izostreno bi lahko rekli, da je njegov »ideal« nekaj, kar naj bi se preko skladateljeve osebnosti uresničevalo kot nova kompozicija. Lajovic se ni natančneje spraševal, kaj je ta »ideal«, ali o tem vsaj ni pisal, prepričan pa je bil, da »ideal« ni skladateljeva zasebna zadeva, pač pa nekaj, kar je povezano z njegovim narodom. S tem, ko skladatelj uresničuje »ideal«, se uresničuje nekaj, kar obstoji v narodu; če skladatelju uspe uresničiti »ideal«, pride do »resonance« med novim umetniškim delom in narodno skupnostjo, kar pomeni, da narodna skupnost novo umetniško delo razume in sprejme.

Zastavlja se vprašanje, kako je Lajovic razlagal in opravičeval dejstvo, da obstoji sočasno veliko število nacionalnih glasbenih kultur, ki so, sledeč njegovim izvajanjem, prav razumljive le pripadnikom vsakokratne narodnostne skupnosti. Iz odlomka $v$ nekem njegovem spisu je razvidno, da se mu je to stanje zdelo naravno in samoumevno; samoumevno se mu je zdelo tudi to, da si vsaka nacionalna kultura prizadeva za svoj obstoj in da se za svoj obstoj in svojo rast tudi bori. Soobstoj različnih nacionalnih kultur, večjih in manjših, močnejših in šibkejših, od katerih si vsaka prizadeva za svoj prostor pod soncem, se mu je zdel nekaj naravnega. Še več: to, da si posamezne kulture prizadevajo za svoj obstoj, četudi so majhne, je nujno za obstoj katere koli kulture, tudi velike; če nacionalne kulture v medsebojnem odnosu ne bi imele trdožive volje po obstoju in rasti, bi propadle, kar bi privedlo do propada kulture nasploh. ${ }^{9}$

V luči takega, darwinistično obarvanega gledanja na kulturo je treba razumeti Lajovičev odpor do prevlade nemških skladateljev na slovenskih koncertnih programih. Nemška obarvanost slovenskega glasbenega življenja je bila zanj znak poraza slovenske glasbene kulture, njena predaja. $\mathrm{Na}$ Slovenskem bi se morala po njegovem mnenju razcveteti slovenska glasba,

8 Lajovic, »O večnih krasotah in o strupu Beethovnovih, Bachovih in Wagnerjevih del«, 124 . 
glasba tu živečih ljudi; le tako bo slovenska glasbena kultura lahko obstala, se vključila $\mathrm{v}$ sicer neenakovredni boj za svoje mesto pod soncem in prispevala svoj delež $\mathrm{k}$ soobstoju različnih nacionalnih glasbenih kultur. To, da se na Slovenskem izvajajo in občudujejo nemški umetniki, se mu je zdela pot k izginotju slovenske kulture. ${ }^{10}$

Lajovičeva gledanja je mogoče razlagati zgodovinsko: Živel je v času, ko so si narodi monarhije prizadevali za samostojnost in se skušali osvoboditi premoči nemške kulture. Sam je bil priča tega, kako se je moč nemške kulture v primerjavi s slovensko porabljala kot ideologija v službi konkretnih političnih ciljev. Protinemška in proslovanska črta sta $v$ njegovem pisanju dobro vidni. ${ }^{I I}$ Vendar lahko v njegovi misli, če jo gledamo zunaj konkretnih zgodovinskih okoliščin, $v$ katerih je nastala, sprevidimo še nekaj drugega: Lajovic se je zavedal, da glasba ni nekaj, kar bi bilo univerzalno razumljivo; da novonastalo glasbeno delo ne more biti razumljivo kjer koli in komur koli; da ima območje, znotraj katerega se lahko novo glasbeno delo recipira, težko premostljive meje. Najbrž ni nenavadno, da je kot območje, znotraj katerega se novo glasbeno delo lahko recipira, prepoznal narodno skupnost.

\section{II}

Če se od Lajovica preselimo k poldrugo desetletje mlajšemu Mariju Kogoju (1892-1956), se srečamo s povsem drugačnim pogledom na umetnost. Kogoj je bil umetnik, predan svojemu umetništvu in zagledan vanj; v svojem času ni bil zmeraj razumljen in tudi danes se njegova glasba različno presoja. Bil je tudi glasbeni kritik in pisec, ${ }^{12}$ in kot je dobro znano, je svoje poglede na umetnost razvil v eseju O umetnosti, posebno glasbeni, objavljenem v reviji Dom in svet v letih 1918/19, ko še ni dopolnil trideset let. ${ }^{13}$

Preden se posvetimo Kogojevi misli, velja opozoriti na naravo njegovega pisanja. Tudi kot pisec esejist je bil Kogoj bolj umetnik kot mislec; bolj kot da bi sistematično razvijal svoje misli, se je predajal pesniško zanesenim besedam o umetnosti in njeni naravi. Tok njegovih misli, kot si sledijo od stavka do stavka in od odstavka do odstavka, ni zmeraj razviden in vča-

A. Lajovic, »Misli o kulturnem tipu germaniziranega Slovenca«, v: Kuret, Umetnik in družba, 115-116.

11 Lajovic, "Misli o kulturnem tipu germaniziranega Slovenca«, 112-114.

12 Borut Loparnik, Zoran Krstulović, »Bibliografija objavljenih besedil Marija Kogoja«, v: Borut Loparnik, Zoran Krstulović, Moja notranjost sem (Ljubljana: NUK, 1992), $38-43$.
} 
sih se približuje prostemu nizanju izjav o umetnosti v obliki maksim. $\mathrm{Ob}$ tem se večkrat zazdi, da si izjave nasprotujejo. Začetne strani Kogojevega eseja kažejo očitni vpliv Ivana Cankarja: Kogoj je po njem povzel slog pisanja, evlogistično opevanje lepote, pa tudi svetobolno podobo umetnika, ki ga družba, ki umetnika sicer potrebuje, ne razume in ne ceni, čeravno jo umetnik močno prekaša. Vse to pomeni, da je treba Kogojeve izjave na neki način prevesti v nepesniški in slogovno nevtralni jezik glasbene estetike.

Kogoj je izhajal iz prepričanja, ki ima v njegovem pisanju močan osebni nadih, da ima umetnost svoj izvor v umetniku kot izjemni osebnosti, ki močno prekaša okolje, v katerem živi. Umetnost izvira izključno iz njegove notranjosti. Umetnik je le to, kar je v njegovi notranjosti. Kogojeva formulacija te misli je: »Moja notranjost sem $« .{ }^{14}$ Misel, da ima umetnost izvor v umetnikovi notranjosti, velja po Kogoju še posebej za glasbo, ki za razliko od drugih umetnosti ne posnema zunanjega sveta. Ker ne posnema zunanjega sveta, lahko posnema ali manifestira le tisto, kar je v umetnikovi notranjosti. ${ }^{\text {is }}$

Postavlja se vprašanje, kaj je ta notranjost, ki se manifestira preko glasbe. V tej zvezi govori Kogoj o lepoti, ki jo umetnik vidi in kateri se želi približati, na nekem mestu pa pravi, da je vsebina umetniškega dela le umetnikovo "čustvo, zgolj estetično čustvo«. ${ }^{16} \mathrm{Z}$ izrazom »čustvo«, kot ga rabi Kogoj, ne gre razumeti česa takega kot človekova vsakodnevna razpoloženja; iz celotnega konteksta njegovega pisanja je razvidno, da je s čustvi pojmoval nekaj mnogo širšega: človekovo notranje življenje ali dinamiko umetnikove notranjosti, ki ga sili proti nekemu nedoločljivemu in nejasnemu cilju, ki ga umetnik sam ne pozna in ne razume. Preko približevanja temu nejasnemu cilju se umetnik uresničuje.

Na prvi pogled so Kogojeve misli o vsebini glasbe protislovne. Na nekem mestu trdi: »Na tem svetu ni ničesar, kar bi moglo biti vzor glasbeno umetniškega snovanja. Ne narava, ne naravni svet. $^{17}$ Malo dalje pravi: „Glasba izraža vse, kar spada v čas in nosi vse lastnosti značajev, vsako stanje ...« V nadaljevanju tega odstavka našteje vrsto duševnih stanj, čustev v ožjem pomenu besede, pa tudi vrsto lastnosti, ki jih imajo predmeti, kot sta barva in vonj. ${ }^{18}$ Spet nadalje beremo: »Kdor hoče slišati glasbo,

\footnotetext{
14 Kogoj, »O umetnosti, posebno glasbeni«, 296.

15 Prav tam, 296.

16 Prav tam, 297.

17 Prav tam, 296.

18 Prav tam, 297.
} 
mora zavrniti program, kajti programsko poslušanje ubija glasbo. ${ }^{19}$ Vse te, na ravni ubeseditve težko uskladljive misli bi bilo mogoče razumeti takole: Kogoj si je morda predstavljal, da kot romanopisec ali slikar nista neodvisna od zunanjega sveta - dogajanja v človeku, družbi, naravi -, tako tudi glasbenik ni neodvisen od tistega, kar vidi, čuti, doživlja; in kot je realnost lahko izvor romanopisja ali slikarstva, tako je lahko tudi izvor glasbe; vendar pa skladatelj - za razliko od romanopisca - pretvarja realnost v vsebino svojega glasbenega dela na strogo enosmerni način, tako, da je kakršna koli vzvratna povezava med glasbenim delom in realnostjo, na osnovi katere je glasbeno delo nastalo, za zmeraj zaprta, tudi za skladatelja samega. Glasbeno delo tako ne more izražati drugega kot »čustva« v pravkar pojasnjenem smislu.

A čeprav izvira umetnost le iz umetnikove notranjosti, po Kogoju ni le stvar umetnika. Podobno kot I. Cankar tudi Kogoj na nekaj mestih trpko omenja, kako družba umetnika ne razume, kako jo moti, da si umetnika ne more podrediti, in kako išče $\mathrm{v}$ umetnosti le zabave in udobja $;^{2 \circ}$ vendar pa družba slednjič mora sprevideti pomen in vrednost umetnikovega dela in ga prizna. ${ }^{21}$ Očitno je, da je Kogoj ločil med zunanjim življenjem vsakokratne sodobne družbe, ki umetnika ne razume, in med nekim drugim, globljim življenjem človeštva. Ne da bi bila kje izrecno izražena, se nakazuje misel, da si je predstavljal, da se preko umetnosti in glasbe, ki jo snuje umetnik v pravkar prikazanem smislu, uresničuje še neki zakriti in globlji smisel družbe in človeštva.

Iz takih izhodišč je Kogoj presojal vse ostalo: Razvoj glasbe je po njegovem prepričanju delo velikih osebnosti, ki jih posnemajo epigoni. ${ }^{22}$ Sloga, ki bi ga ustvarila skupina ljudi ali doba, ni; slog je delo posameznika. ${ }^{23}$ Umetnik je pri svojem delu svoboden $\mathrm{v}$ absolutnem smislu: $\mathrm{s}$ toni dela kar koli; ne ovirajo ga ne uveljavljene tehnike ne okus dobe; ${ }^{24} \mathrm{v}$ harmonskem pogledu to pomeni, da povsem prosto sestavlja akorde iz dvanajstih tonov; katera koli kombinacija je možna. ${ }^{25}$

$\mathrm{Ni}$ mogoče spregledati, da ima $\mathrm{v}$ Kogojevem pogledu na umetnost ključno vlogo umetnik, ki mu Kogoj pripisuje neke vrste duhovniško vlo-

\footnotetext{
19 Prav tam, 298.

20 Prav tam, 293, 303-304.

21 Prav tam, 295, 302.

22 Prav tam, 294-295.

23 Prav tam, 305.

24 Prav tam, 307.

25 Prav tam, 310.
} 
go. ${ }^{26}$ Podoben kult umetnika bi lahko v različnih variantah iskali pri številnih piscih poznega 19. in zgodnjega 20. stol. Dejstvo, da ima tudi v Kogojevem pogledu tako pomembno mesto, je možno razlagati s stališča njegovega osebnega položaja: Kot napredni umetnik svojega časa je najbrž čutil potrebo, da se nasloni na estetiko, ki je glasbi kot delu umetnikov pripisala metafizične razsežnosti.

\section{III}

V pisanju Stanka Vurnika (1898-1932) se srečamo s povsem drugačnim pristopom k umetnosti. Sin organista in skladatelja Mateja Vurnika je bil prvenstveno umetnostni zgodovinar. Na Univerzi v Ljubljani je doktoriral pri Izidorju Cankarju, ki je bil sam učenec Maxa Dvořaka na Dunaju, in sicer z disertacijo o slikarju Janezu Valentinu Metzingerju. Poleg umetnostne zgodovine se je posvečal etnologiji in glasbi. ${ }^{27}$ Čeprav je umrl mlad, je zapustil velik opus raznovrstnih spisov; če se omejimo na umetno glasbo, so to časopisne kritike, ocene glasbenih sezon, polemični prispevki ${ }^{28}$ in dve razpravi: Uvod v glasbo. I. Sistematični del ${ }^{29}$ in Stil $v$ zgodovini glasbe; ${ }^{30}$ slednja naj bi bila kot stilna zgodovina glasbe smiselno dopolnilo Uvoda, vendar je Vurnik uspel dokončati le poglavje o glasbi antične Grčije. Vurnikova misel o glasbi je bila doslej le nekajkrat predmet temeljitejšega muzikološkega razpravljanja. ${ }^{31}$

26 Prav tam, 293.

27 Vilko Novak, Peter Krečič, Kristijan Ukmar, »Vurnik, Stanko«, Slovenska biografija (splet).

28 Izbor pomembnejših Vurnikovih časopisnih prispevkov je objavil Kuret, Umetnik in družba, 337-476.

29 Stanko Vurnik, Uvod v glasbo. I. Sistematični del (Ljubljana: Nova založba, 1929). Pred tem je besedilo v nadaljevanjih izhajalo v reviji Dom in svet 41 (1928). Kot pravi v uvodu, je Vurnik za knjižno izdajo besedilo preuredil. Podnaslov dela in oštevilčenje napovedujeta nedokončani Stil v zgodovini glasbe. - Zunanje okoliščine nastanka Uvoda in Stila so prikazane v delu: Kristijan Ukmar, »Problem stila v interpretaciji Stanka Vurnika«, Muzikološki zbornik 3 (1967): 78.

30 Dom in svet 44, št. 3/4-10 (1931).

31 Ukmar, »Problem stila«, 77-87. Kuret, »Slovenska glasbena misel po prvi vojni«, 7-79. Omeniti velja še dve diplomski nalogi: Kristijan Ukmar, Stanko Vurnik: življenje in delo (Ljubljana: Filozofska fakulteta, 1964); Karmen Salmič Kovačič, Vpliv estetske misli Franceta Vebra na Uvod v glasbo Stanka Vurnika (Ljubljana: Filozofska fakulteta, 1990). - Tisti, ki smo poslušali predavanja Vilka Ukmarja, lahko ob branju Vurnikovega Uvoda ugotavljamo, da je bil glavni vir Ukmarjevega razpravljanja prav Vurnik. V Uvodu skorajda ni mesta, ki ne bi imelo v Ukmarjevih predavanjih nekega odmeva. Ukmar je sooblikoval pogled na glasbo številnim generacijam slovenskih 
Vurnikovo pisanje ni neproblematično. Čeprav je njegova misel v glavnih obrisih lahko razpoznavna, je mestoma nejasna: Morda je ponekod premalo natančno obrazložil, kaj pravzaprav misli; tovrstna mesta so še zlasti težko razumljiva, če jih beremo s skoraj stoletne časovne razdalje. Mestoma naletimo na odlomke, ki so $\mathrm{v}$ kompilativnem smislu navrženi brez prave zveze z glavnim tokom misli ali pa jih ni mogoče uskladiti s celoto. Tudi pri rabi pojmov je puščal bralca $\mathrm{v}$ dvomu; zelo pogosto se pri njem pojavi izraz »čutno«, ki ima nasploh zelo širok pomenski obseg. Vurnik nikjer ne obrazloži, kaj točno pomeni: ali to, da vzbuja glasbeno delo določene občutke in čustva, ali moralno vprašljivi hedonizem ali še kaj drugega.

Razlog za prikazano naravo Vurnikovega pisanja je mogoče videti $\mathrm{v}$ dvojem: (1) Svoj pogled na umetnost in glasbo si je Vurnik pridobival z branjem ustrezne literature. ${ }^{32} \mathrm{Zdi}$ se, da so njegovi spisi nastajali kot kompilacija tistega, kar je bral, pri čemer je prebrano vsebino na neki način prilagajal in predelaval. Vendar je bil pri kompiliranju svojih spisov premalo samokritičen; za področje, ki se ga je loteval, za eksaktno področje glasbene estetike, ni razvil ustrezne miselne discipline. (2) Vurnik ni ločeval med zgodovinskimi in glasbenoestetskimi spoznanji; interpretacije glasbenozgodovinskih dejstev, glasbe nasploh in posameznih skladb, interpretacije, ki so veljavne le znotraj določenega miselnega sistema, je imel za zgodovinska dejstva. Ker so misli, ki jih je kompilativno sprejemal kot dejstva, izhajale iz različnih smeri, je tok njegovega pisanja nujno večkrat neusklajen; v njegovih spisih so tako mesta, ki bralcu zamegljujejo pogled na celoto, ki niso niti izdelana niti jim ni mogoče najti ustreznega mesta v vsebinskem toku celote.

Vurnikovo pisanje se bere danes precej drugače kot $\mathrm{v}$ njegovem času, še zlasti, če pomislimo, da je bil pogled na zgodovino glasbe pred stoletjem bistveno drugačen od današnjega, in da je bila estetska in filozofska misel o glasbi v slovenskem kulturnem prostoru med obema vojnama nekaj novega. Sodobno branje Vurnikovih spisov je branje s stališča drugega miselnega okolja. Če hočemo obrise Vurnikove misli prav spoznati, je nujno, da jih predstavimo, tako kot $\mathrm{v}$ Lajovičevem in Kogojevem primeru, v sodobnem jeziku in s sodobno terminologijo; pri tem je treba mestoma razločno izraziti tudi tisto, kar Vurnikovo pisanje implicira, ne da bi bilo izrecno zapisano. Ker Vurnikovo pisanje ni povsem usklajeno, je razumljivo, da lahko tako postopanje privede tudi do nasprotujočih si zaključkov.

glasbenikov in muzikologov; Vurnikove misli o glasbi predstavljajo tako pomemben segment slovenske kulturne zgodovine.

32 Vurnik redko navaja kako literaturo. Katera dela s področja glasbe je poznal in uporabljal, je skušal dognati K. Ukmar, »Problem stila«, 78-79. 
Oglejmo si zdaj obrise Vurnikove misli. ${ }^{33}$ Vurnik je bil umetnostni zgodovinar in zato je bil njegov pristop h glasbi kot predmetu misli bistveno drugačen od Kogojevega, ki je glasbo razumel le kot delo umetnika. Vurnik je glasbo gledal kot družbeno danost in širok zgodovinski pojav, ki presega posameznika. S tega zornega kota - zornega kota zgodovinarja - je presojal obdobja, posamezne umetnike in posamezna glasbena dela.

V predgovoru v svoj Uvod Vurnik pove, da skuša odgovoriti na vprašanje, kaj je »umetnostna vsebina glasbe«, kaj njen "pomen«, zaprt v »formo.$^{34} \mathrm{~V}$ tem se nakazuje misel, ki pogosto zaveje iz njegovega pisanja, misel, da pomen glasbenega dela ni v glasbi sami, pač pa v ideji kot ubesedljivi misli, ki jo lahko prepoznamo v glasbi.

Kot je razvidno iz nadaljevanja, je bil Vurnik prepričan, da je umetnost povezana s svojim okoljem na racionalno spoznavni in razložljivi način. Predstavljal si je, da umetnost dobe, zgodovinskega okolja in umetnost posameznika v njem nujno izraža prevladujoči svetovni nazor svoje dobe ali zgodovinskega okolja: svetovni nazor, ki se da izraziti $z$ besedami kot določeni pogled na svet in človeka $\mathrm{v}$ njem. Za kateri koli svetovni nazor je menil, da ga je možno določiti z mestom na enodimenzionalni premici, na katere enem koncu je skrajni idealizem, ki priznava le obstoj duhovnega, na drugi pa skrajni materializem, imenovan pri njem tudi naturalizem, ki priznava le obstoj materialnega; med obema skrajnostma je po Vurniku realizem, ki priznava oboje. ${ }^{35}$ Kateri koli svetovni nazor je bodisi bliže idealizmu ali pa bliže materializmu. V tem smislu se je posluževal oznak kot »idealistični realizem «, "naturalistični realizem $\aleph^{36} \mathrm{ipd}$.

Vsaka doba naj bi imela po Vurniku svoj značilni in prevladujoči svetovni nazor, znotraj katerega so sicer obstajale na prostor ali na kaj drugega vezane različice. Srednji vek naj bi bil izazito idealističen, sledeče obdobje renesanse naturalistično. ${ }^{37}$ Prevladujoči svetovni nazor naj bi bil, kot je bilo omenjeno, razviden tudi v prevladujočem slogu dobe, $v$ tem smislu, da se svetovni nazor izraža preko sloga.$^{38} \mathrm{~V}$ zgodovini se iz obdobja v obdobje menja svetovni nazor, pogled na svet, občutevanje sveta, način življenja, in obenem s tem se iz obdobja v obdobje menja tudi slog. Zmeraj se uvelja-

33 Vurnik je osnovni pogled na umetnost prevzel po svojem učitelju Izidorju Cankarju. Ukmar, »Problem stila«, 78-79 in na več nadaljnjih mestih.

34 Vurnik, Uvod, 5.

35 Prav tam, 129.

36 Prav tam, 85.

37 Prav tam, 153.

38 Prav tam, 146. 
vi tisti novi umetnostni slog, ki ustreza svoji dobi, njeni miselnosti, načinu življenja, slog, ki izraža novi svetovni nazor dobe. Gledano s tega zornega kota se je Vurniku zdela zgodovina umetnosti zelo zanimiva: primerjal jo je s polifonim tokom, v katerem je zmeraj nekaj novega. Spričo povezave umetnostnega sloga s svetovnim nazorom si je predstavljal, da je preko spoznavanja umetniških del mogoče spoznavati zgodovino in tisto, kar se je miselnega, svetovnonazorskega dogajalo v njej. ${ }^{39}$

Če se ustavimo ob Vurnikovem pojmovanju sloga, lahko opozorimo na dvoje:

1) Za Vurnika je slog nekaj, kar je nad posameznimi umetnostmi: isti značilni slog dobe, ki obvladuje slikarstvo, je prisoten tudi v sočasni literaturi, glasbi itd.

2) Glede razmerja med svetovnim nazorom in slogom velja opomniti, da ima v Vurnikovi misli prvenstvo svetovni nazor, ki je pred slogom, če že ne časovno pa gotovo pomensko.

Kako natančneje nastane novi slog, je Vurnik nakazal v nekem drugem spisu: Predstavljal si je, da obstojijo določeni družbeni krogi, »vplivne sfere«, in znotraj njih »umetnostnomerodajni krogi«, kot jih je imenoval, s čimer si lahko predstavljamo ustvarjajoče umetnike. V vplivnih družbenih krogih nastajajo predispozicije, izhodišča, iz katerih lahko ustvarjajoči umetniki ustvarjajo nova dela in razvijejo novi slog, ki se razširi povsod tam, kjer obstojijo ustrezne miselne predispozicije zanj. Predispozicije, iz katerih nastane nova umetnost, niso glasbene; so splošne duhovne, miselne danosti, svetovni nazor dobe. Novi slog se uveljavi, če je v skladu s celotno duhovno atmosfero svojega časa in prostora. ${ }^{40}$

S temi mislimi je določena tudi vloga umetnika: Novo umetniško delo mora biti v skladu s predispozicijami, kot se oblikujejo v "vplivnih sferah«. Le v tem primeru lahko družbeno okolje novo umetniško delo sprejme. To pomeni, da umetnik ne ustvarja iz sebe, iz svoje notranjosti; pravi vir njegove umetnosti je okolje, v katerem živi. ${ }^{41}$ Novi slog vpelje genialna osebnost, ki prepozna značilnosti dobe, njenega duha, njen nazor, vse to na neki način vsrka, in izhajajoč iz tega ustvari novi slog, ki ustreza času. Geniju sledi plejada epigonov, ki razširijo in napravijo vsesplošno tisto, kar je

39 Prav tam, 163-164.

40 Stanko Vurnik, »Umetnost in družba ter umetnostna politika«, v: Kuret, Umetnik in družba, 365,367 .

41 Stanko Vurnik, »O glasbi sploh in o moderni glasbi posebej«, v: Kuret, Umetnik in družba, 395. 
odkril genij, dokler se spet ne spremeni duh dobe in se pojavi novi genij. ${ }^{42}$ Vlogo umetnika je Vurnik podal s primero: zgodovinski tok je kot polifonija, odločilni umetniki, tvorci novega sloga, so njen ritem. ${ }^{43} \mathrm{~V}$ smislu tega gledanja je bil Vurniku umetniški individualizem sumljiv; to, da umetnik ustvarja le iz sebe, se mu je zdelo toliko, kot da bi ustvarjal le zase. Po Vurniku se tak umetnik izloči iz družbe, saj je razumljiv le samemu sebi. ${ }^{44}$

Okolje, v katerem nastane novi slog, po Vurniku nikakor ni istovetno $\mathrm{z}$ narodnostno skupnostjo. Prav nasprotno. Vurnik je duhovno atmosfero katerega koli časa, znotraj katere nastane ustrezni slog, videl kot nekaj, kar obstoji mimo narodnostnih meja. Da je tako, mu je po eni strani kazala zgodovina umetnosti, po drugi pa tudi številni primeri iz sodobnega življenja. Vurnik si je sicer predstavljal, da lahko hkrati obstoji več okolij, znotraj katerih se generirajo novi slogi, vendar se ta okolja v njegovi misli nikakor ne pokrivajo $\mathrm{z}$ nacionalnimi mejami: slogi nastajajo, obstojijo in se razvijajo mimo narodnostnih meja. Umetniško snovanje je bilo za Vurnika izrazito nenacionalna, nacionalno spregledujoča dejavnost. ${ }^{45}$ Misel je še izostril: Bolj ko je umetnost nacionalna, bolj je individualistična, bolj zaprta, s tem pa v vse manjši meri tisto, kar bi kot umetnost morala biti. ${ }^{46}$

Vurnikovo razpravljanje ne bi bilo razpravljanje o glasbi, če ne bi teh misli apliciral na glasbo. Kot je razvidno že iz naslovov poglavij v njegovem Uvodu, je v glasbi ločil troje vsebin, kot jih je imenoval: Prva, »formalna vsebina « je vse tisto, kar je v glasbi zgolj glasbenega, tisto, kar more s svojim glasbenoteoretičnim aparatom prepoznati glasbena analiza. Druga, "predmetna vsebina« glasbe je tisto, kar je v glasbi zunajglasbenega in se da opisati $z$ besedami. $Z$ ozirom na predmetno vsebino se vsaka kompozicija uvršča med dve skrajnosti: na eni strani je glasba brez predmetne vsebine, pri kateri je vsa vsebina v njeni obliki - primer bi bil lahko kaka abstraktna fuga -, na drugi programsko deskriptivna glasba. Beethovnove kompozicije so nekako na sredi: očitno je, da pripovedujejo nekaj, kar bi se dalo izraziti v obliki zgodbe, vendar pa noben poskus določitve predmetne vsebine Beethovnovih skladb ni zanesljiv. Zdi se, da je Vurnik verjel, da predmetne vsebine Beethovnovih kompozicij objektivno obstojijo, le odkriti jih ni mogoče. ${ }^{47}$

42 Vurnik, Uvod, 159-160.

43 Vurnik, Uvod, 162.

44 Vurnik, »O glasbi sploh in o moderni glasbi posebej«, 396.

45 Vurnik, »Umetnost in družba«, 365.

46 Prav tam, 366. Stanko Vurnik, »Nova muzika«, v: Kuret, Umetnik in družba, 394.

47 Vurnik, Uvod, 104. 
Tretja vsebina glasbe je »estetska vsebina«; $\mathrm{z}$ ozirom na to je glasba lahko le lepa ali grda. Ni jasno, kot kaj si je Vurnik predstavljal estetsko vsebino. Poglavje o estetski vsebini govori namreč predvsem o svetovnem nazoru in o tem, kako se le-ta izraža v glasbi. Domnevno si je Vurnik predstavljal, da je glasba lepa, če se v njej idealno skladata formalna in predmetna vsebina, in se hkrati preko njenega sloga razločno izraža tudi določeni svetovni nazor. ${ }^{48}$

Ko v poglavju o estetski vsebini Vurnik razmišlja o tem, kako naj bi se svetovni nazor izražal v glasbi, kaj naj bi bila njena svetovnonazorska vsebina, glasbe ne razumeva $\mathrm{v}$ njenem glasbenoestetskem bistvu, pač pa skuša slog in svetovni nazor, iz katerega izhaja, razbrati v samem glasbenem in kompozicijskem gradivu, $v$ tistem, kar je sam imenoval formalna vsebina, tj. v glasbenih teoremih, abstrahiranih iz same glasbe, in $\mathrm{v}$ abstrahiranih kompozicijskih tehnikah in postopkih. Temu je pripisoval slogovno vrednost, s tem pa implicitno tudi to, da so izraz določenega svetovnega nazora. Tako naj bi bilo po njegovem mnenju srednjeveško koralno enoglasje izraz idealizma, zato, ker nima možnosti čutnega učinkovanja; polifona umetnost 15. in 16. stol., ki sestoji sicer iz nečutnih melodij, vendar ima njihov preplet nekaj čutnega, naj bi bila izraz realizma; homofonija - prevlada ene, $\mathrm{v}$ smislu funkcijske harmonije zasnovane in razumljene melodije pa naj bi bila izraz naturalizma, saj učinkuje predvsem čutno. ${ }^{49}$

Iz takih interpretacij je možno izpeljati Vurnikovo gledanje na kompozicijsko tehniko. Vurnik večkrat poudari, da je gonilo razvoja človeški duh, ne pa razvoj kompozicijske tehnike. ${ }^{50}$ To pomeni, da je vse tisto, kar je sam imenoval formalna vsebine, tj. kompozicijski postopki, zgolj sredstvo, preko katerega se izraža določena ideja, določeni svetovni nazor. Posledično se na več mestih njegovega pisanja ustvarja vtis, da si je predstavljal, da obstojijo glasbeni teoremi in kompozicijske tehnike ločeno od skladateljev, da so apriorno dani, da so celo zunaj zgodovinskega razvoja, in da se jih skladatelji poslužujejo z ozirom na svoj od svetovnega nazora odvisni slog. Srednjeveški koral je torej enoglasen zaradi idealizma, ki naj bi obvladoval celotni srednji vek; tvorci korala bi po Vurnikovem mnenju lahko komponirali tudi večglasno, če ne bi bili usmerjeni tako strogo idealistično.

Ob tem, ko je Vurnik na prikazani način abstraktom kompozicijskih postopkov skušal pripisati slogovne in nazorske vrednosti, je nujno zašel

48 Prav tam, 131-132.

49 Prav tam, 130-131.

50 Prav tam, 128, 156. 
$\mathrm{v}$ težave. Interpretiranje obdobij, smeri, skladateljev in njihovih del $\mathrm{v}$ tem smislu ga je privedlo do težko razumljivih trditev in $\mathrm{v}$ isti skupini so se znašle močno različne stvari. Za primer lahko vzamemo Vurnikove ponazoritve naturalizma: programska instrumentalna glasba, kot npr. Smetanova Domovina, je po njegovem naturalistična; ${ }^{51}$ a tudi čista instrumentalna glasba, ki razen svoje oblike nima nobene vsebine, je znak »čutno - materialističnega časa«; taka glasba je zgolj »igračkanje s formami« brez vsake vsebine; ${ }^{52}$ za primere take glasbe daje Vurnik tudi Bachove fuge, katerih teme so "plitev nič «; $;$ hkrati je odraz naturalizma tudi vsa plesna glasba vključno z Dvořakovimi Slovanskimi plesi, saj ples s svojim poudarjeno ritmičnim impulzom učinkuje predvsem na čute in nima nobene druge vsebine. ${ }^{54} \mathrm{Vu}-$ rnikovo razpravljanje o tem, kako se svetovni nazor odraža $v$ formalni vsebini, ni ne razumljivo ne obnovljivo.

Kot je bilo omenjeno na začetku prikaza Vurnikove misli, si je predstavljal, da mora biti tisto, kar kompozicija izraža, kar po svojem bistvu je, njen svetovni nazor torej, takšne vrste, da se ga da izraziti kot ubesedljivo idejo. Ta pogled je morda najbolj razločno izražen v njegovi analizi koralnega introita Statuit ei Dominus. .5 Glasba je tu po Vurnikovem mnenju omejena na to, da nosi besedilo, podčrtuje njegovo vsebino, ki je izraz krščansko-idealističnega pogleda na svet. Učinek same glasbe je pri tem ničen; celotni introit kot spev izraža torej le tisto, kar izraža njegovo besedilo. Nasprotni pol taki glasbi predstavlja glasba kot »igračkanje s formami« brez vsebine, kjer gre zgolj za glasbeno umetnijo brez čustev in idej. ${ }^{56}$ Kot omenjeno, sodijo po Vurniku v to skupino tudi Bachove fuge.

Ob koncu tega pregleda lahko opozorimo na nekaj dilem. Misli, ki so jih razvili Lajovic, Kogoj in Vurnik, gotovo niso bile samo njihove. V raznih variantah bi jih lahko našli v številnih spisih o glasbi, zlasti nemških, s konca 19. in začetka 20. stol. Poznavalci glasbene estetike bi v njih težko prepoznali kaj novega. Vendar pa to ne pomeni, da so bili Lajovic, Kogoj in Vurnik zgolj eklektični epigoni brez osebnostnih potez. Najmanj, kar je v tej zvezi

51 Prav tam, 101.

52 Vurnik, »O glasbi sploh in o moderni glasbi posebej«, 395.

53 Vurnik, Uvod, 122.

54 Prav tam, 124-125. O Vurnikovih zagatah gl. tudi Ukmar, »Problem stila«, 83-84.

55 Vurnik, Uvod, 61-64.

56 Vurnik, »O glasbi sploh in o moderni glasbi posebej«, 395. 
možno reči, je, da so si svoje poglede oblikovali na ozadju širše sočasne ali polpretekle misli o umetnosti in glasbi, bodisi da so jo poznali iz primarnih virov ali preko takega ali drugačnega posredništva.

Kot je bilo že nakazano, je misli vsakega od treh predstavljenih esejistov mogoče interpretirati s stališča njegove življenjske poti: Lajovic je bil otrok časa, ko je slovenska skupnost stremela h kulturni samostojnosti, in razumljivo je, da se je zavzemal za slovensko glasbo; Kogoj je bil umetnik, ki bi potreboval brezpogojno družbeno priznanje umetniškega delovanja; Vurnik je bil umetnostni zgodovinar, ki je ideje svojega učitelja skušal prenesti na glasbo. Zastavlja se vprašanje, ali ta dejstva omejujejo veljavnost njihovih pogledov ali pa so le-ti s tem, da so $\mathrm{v}$ odvisnostni povezavi $\mathrm{z}$ življenjskimi potmi njihovih nosilcev, pravi odraz razmer in časa, $v$ katerem so imenovani trije živeli.

Vsak od treh predstavljenih esejistov si je ustvaril lastni pogled na glasbo. Razlike med njimi so bile v času njihovega delovanja opazne, nemalokrat so imele tudi polemični značaj, saj je Lajovic javno polemiziral tako s Kogojem kot z Vurnikom. Tudi danes ni mogoče spregledati različnosti njihovih izhodišč in pogledov, čeravno se s skoraj stoletne zgodovinske perspektive njihova razmišljanja kažejo kot del istega kulturnega sveta. Sprašujemo se lahko, ali je prikaz njihovih misli hkrati tudi prikaz slovenske medvojne misli o glasbi ali pa je treba Lajovica, Kogoja in Vurnika gledati kot tri individualne osebnosti z različnimi pogledi na bistvena vprašanja $\mathrm{v}$ zvezi z glasbo.

\section{Bibliografija}

Barbo, Matjaž. Uvod v muzikologijo. Ljubljana: Znanstvena založba Filozofske fakultete, 2016.

Cvetko, Dragotin. Glasbeni svet Antona Lajovca. Ljubljana: SAZU, 1985.

Kogoj, Marij. »O umetnosti, posebno glasbeni«. V: Kuret, Primož. Umetnik in družba. Ljubljana: Državna založba Slovenije, 1988, 291-311.

Koter, Darja. Slovenska glasba 1918-1991. Ljubljana: Študentska založba, 2012.

Kuret, Primož. »Slovenska glasbena misel po prvi vojni«. V: Kuret, Primož. Umetnik in družba. Ljubljana: Državna založba Slovenije, 1988, 7-79.

Kuret, Primož. Umetnik in družba. Slovenska glasbena misel po prvi vojni. Lajovic, Kogoj, Vurnik. Ljubljana: Državna založba Slovenije, 1988.

Lajovic, Anton. »Misli o kulturnem tipu germaniziranega Slovenca«. V: Kuret, Primož. Umetnik in družba. Ljubljana: Državna založba Slovenije, 1988, 112-116. 
Lajovic, Anton. »Misli o umetnostni politiki«. V: Kuret, Primož. Umetnik in družba. Ljubljana: Državna založba Slovenije, 1988, 171-185.

Lajovic, Anton. »O nacionalnosti v umetnosti«. V: Kuret, Primož. Umetnik in družba. Ljubljana: Državna založba Slovenije, 1988, 133-135.

Lajovic, Anton. „O večnih krasotah in o strupu Beethovnovih, Bachovih in Wagnerjevih del«. V: Kuret, Primož. Umetnik in družba. Ljubljana: Državna založba Slovenije, 1988, 124-127.

Loparnik, Borut, in Krstulović, Zoran. »Bibliografija objavljenih besedil Marija Kogoja«. V: Loparnik, Borut, in Krstulović, Zoran. Moja notranjost sem. Ljubljana: NUK, 1992, 38-43.

Novak, Vilko, Krečič, Peter in Ukmar, Kristijan. »Vurnik, Stanko«. Slovenska biografija (splet).

Pompe, Gregor. »Glasba slovenske povojne moderne«. De musica disserenda 12, št. 2 (2016): 23-46.

Salmič Kovačič, Karmen. Vpliv estetske misli Franceta Vebra na Uvod v glasbo Stanka Vurnika. Ljubljana: Filozofska fakulteta, 1990 (diplomsko delo).

Škerjanc, Lucijan Marija. Anton Lajovic. Ljubljana: SAZU, 1985.

Ukmar, Kristijan. »Problem stila v interpretaciji Stanka Vurnika«. Muzikološki zbornik 3 (1967): 77-88.

Ukmar, Kristijan. Stanko Vurnik: življenje in delo. Ljubljana: Filozofska fakulteta, 1964 (diplomsko delo).

Vurnik, Stanko. »Nova muzika«. V: Kuret, Primož. Umetnik in družba. Ljubljana: Državna založba Slovenije, 1988, 392-394.

Vurnik, Stanko. »O glasbi sploh in o moderni glasbi posebej«. V: Kuret, Primož. Umetnik in družba. Ljubljana: Državna založba Slovenije, 1988, 394-397.

Vurnik, Stanko. »Stil v zgodovini glasbe«. Dom in svet 44, št. 3/4-10 (1931).

Vurnik, Stanko. »Umetnost in družba ter umetnostna politika«. V: Kuret, Primož. Umetnik in družba. Ljubljana: Državna založba Slovenije, 1988, 364-370.

Vurnik, Stanko. Uvod v glasbo. Ljubljana: Nova založba, 1929. ${ }^{57}$

57 Poglavje je nastalo kot del projekta J6-7180, ki ga je sofinancirala Agencija za raziskovalno dejavnost Republike Slovenije.

This chapter is part of the project J6-7180 funded by Slovenian research agency ARRS, 